
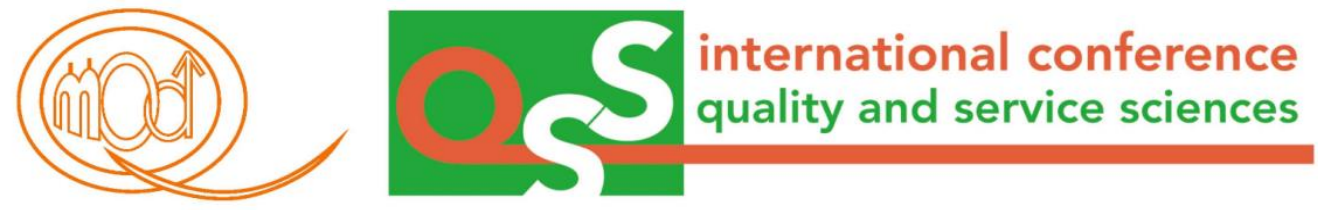

\title{
$17^{\text {th }}$ QMOD-ICQSS
}

\section{PROCEEDINGS \\ Part 2: INDEX and FULL PAPERS}

$3^{\text {rd }}-5^{\text {th }}$ September, 2014

Prague, Czech Republic

Editors:

Su Mi Dahlgaard-Park Jens J. Dahlgaard

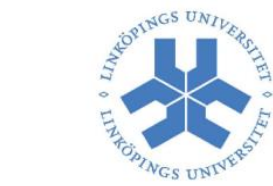

Linköping University

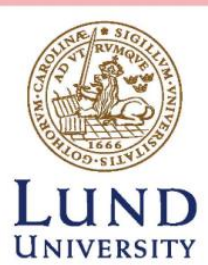




\title{
Customer experience management and business performance
}

\author{
Lars Grønholdt \\ Professor, Department of Marketing \\ Copenhagen Business School, Denmark \\ LG.marktg@cbs.dk \\ Anne Martensen \\ Associate Professor, Department of Marketing \\ Copenhagen Business School, Denmark \\ AM.marktg@cbs.dk \\ Stig Jørgensen \\ Director, Customer and Market Development \\ Rambøll Management Consulting, Denmark \\ STGJ@ramboll.com \\ Peter Jensen \\ Market Manager, Customer and Market Development \\ Rambøll Management Consulting, Denmark \\ PTEJ@ramboll.com
}

\begin{abstract}
Purpose - The purpose of this paper is to examine how essential dimensions of customer experience management (CEM) drive business performance in Danish companies.

Methodology/approach - An empirical study is conducted to investigate the relationships between seven CEM dimensions, differentiation, market performance and financial performance. The conceptual model is operationalized by a structural equation model, and the model is estimated and tested by using the partial least squares method. A survey among 484 companies in Denmark forms the empirical basis for the study.
\end{abstract}

Findings - The findings provide evidence that the seven CEM dimensions influence financial performance. The high performing companies differentiate significantly from the low performing companies with regard to how they master CEM. All seven CEM dimensions are essential in producing differentiation, market performance and financial performance.

Research limitations - This study is limited to the seven identified CEM dimensions in Danish companies. 
Practical implications - This study has clear implications in terms of identifying and measuring the importance of essential CEM dimensions which influence business performance. The results can help companies to understand CEM and develop CEM strategies.

Originality/value - The paper provides a deeper insight into CEM and how CEM works.

Key words: Customer experience, Emotions, Differentiation, Market performance, Financial performance

Paper type: Research paper

\section{Introduction}

In recent years, creating and managing customer experiences seems to be a key area for most companies, particularly for those in the service sector, and the topic of customer experience has attracted great attention from marketing academics and practitioners (Lywood et al., 2009; Palmer, 2008, 2010; Pullman and Gross, 2004; Verhoef et al., 2009). Sharma and Chaubey (2014, p. 18) claim that "the customer experience has emerged as the single most important aspect in achieving success for companies across all industries".

Consumer research shows that "experiences occur when consumers search for products, when they shop for them and receive service, and when they consume them" (Brakus et al., 2009, p. 52). That is, the experiences include product and service experiences during the customer's product search in the pre-purchase phase (decision process), purchase phase, use and postpurchase and phase.

Pine and Gilmore (1998, p. 12) describe successful experiences as those that "a customer finds unique, memorable and sustainable over time", and Schmitt (1999, p. 26) emphasizes that customer experiences "provide sensory, emotional, cognitive, behavioral and relational values that replace functional values".

Business scholars and practitioners have been increasingly aware of the need to create value for customers in the form of the 'emotionally' customer experience (Lynch and de Chernatony, 2004; Shaw, 2004, 2007; Shaw and Ivens, 2005; Tumbat, 2011), the 'total' customer experience (Mascarenhas et al., 2006), the 'perfect' customer experience (Frow and Payne, 2007), and the 'outstanding' customer experience (Frow and Payne, 2007).

The uniqueness of customer experience can lead to differentiation and competitive advantage (Bagdare and Jain, 2013; Schmitt, 1999). In this way, creating and delivering customer experience is essential for enhancement of relationships with customers and building customer loyalty, and thus provides economic value for companies (Brakus et al., 2009; Frow and Payne, 2007; Lywood et al., 2009; Mascarenhas et al., 2006). Differentiating solely on the traditional elements such as product quality, service quality, and price is no longer a sufficient business strategy, and "companies must find new ways to achieve a competitive advantage particularly by focusing and management of customers' experience" (Pullman and Gross, 2004, p. 551). 
The literature on customer experience is growing fast and the debate among scholars and practitioners is very lively. However, "the greatest challenge for customer experience management lies in the difficulty of measuring the concept, which is specific to a situational and emotional context" (Palmer, 2008). Moreover, Brakes et al. (2009, p. 52) state that "research has largely ignored the exact nature and dimensional structure of brand experiences". The present study addresses these challenges and examines how customer experience management (CEM) can be measured and how different dimensions of CEM influence business performance.

The present study is initiated and conducted as a research project in collaboration with academics at Copenhagen Business School (www.cbs.dk) and practitioners at Rambøll Management Consulting (www.ramboll.com/management-consulting).

The structure of the paper is as follows. In the next section, we identify essential dimensions of CEM and propose a conceptual model of the relationships between these CEM dimensions and business performance. The research methodology is described in the third section. The fourth section presents the results of data analysis, and the findings are intensively discussed in the fifth section. We finish with managerial implications and with concluding remarks.

\section{Linking CEM to business performance}

Based on literature review, case studies from the literature (i.a., Frow and Payne, 2007; Kotler and Pfoertsch, 2006; Mascarenhas et al., 2007) and practical work with CEM an initial frame of reference of CEM was developed. This outlined a set of eight characteristics of CEM describing relevant areas of actions in the company: Top management involvement, customer touch points, customer focus, goals for customer experiences, customer insight, customerdriven innovation, employee recruitment and training, and branding, i.e. ensuring that the customer experience is delivered in a way that stays true to the brand promise.

For each of the characteristics survey questions have been developed based on Shaw (2004, 2007), Shaw and Ivens (2005) and practical work with CEM surveys. An empirical study (see next section) suggested that it would be appropriate to organize the initial CEM characteristics in seven CEM dimensions. Hence, analyzing survey responses from 484 companies using factor analysis (see next section) gave new insight into how to best structure and describe the CEM concept but at the same time dimensions that make even more sense. The seven dimensions (factors) are shown at the left hand side of Figure 1.

It is important to notice that two of the dimensions are specific devoted to rational aspects, whereas two other dimensions are devoted to emotional aspects. This distinction is important due to the fact that customer experiences can be rational (for example experiences of functional product quality, price and delivery time) and/or emotional involving the customer's affective system through the generation of moods, feelings and emotions. The customer's involvement at a rational and emotional level is also highlighted in the literature on customer experience (Gentile et al., 2007). 
Figure 1. The conceptual CEM model

Customer Experience Management

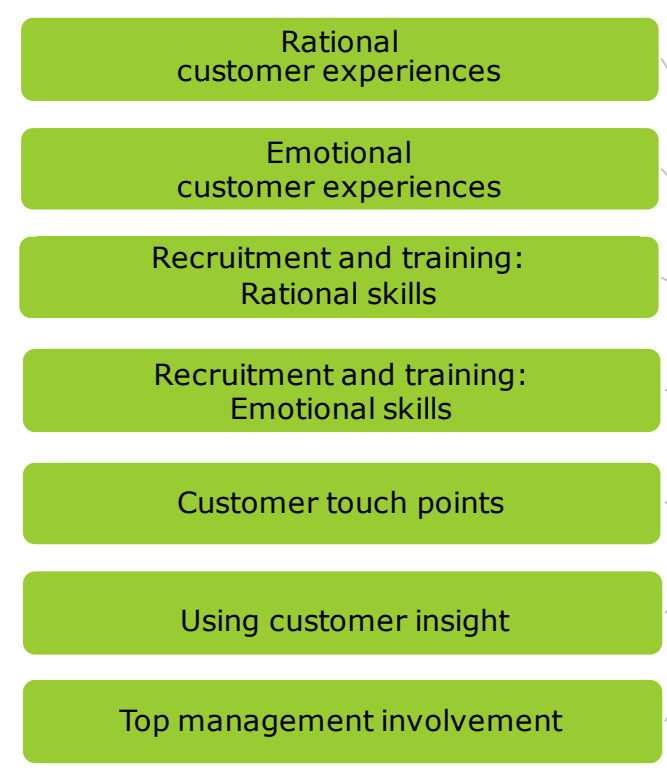

Competitive advantage

Business performance
Market

performance

Financial performance

The power of emotions has been emphasized in the literature on CEM, both in business-toconsumer markets (Pullman and Gross, 2004; Shaw, 2004, 2007; Shaw and Ivens, 2005) and in business-to-business markets (Kotler and Pfoertsch, 2006; Lynch and de Chernatony, 2004). The emotional components are important especially when the functional benefits of products and services are difficult to evaluate. Consumer behavior researchers "tell us that economic decision-making is 70 percent emotional and 30 percent rational" (Balakrishnan, 2011, p. 222).

The model in Figure 1 shows the links between CEM, market performance and subsequently financial performance. Differentiation has been added as a mediating variable. It is through differentiation - market differentiation as well as innovation differentiation - companies will be able to achieve a competitive advantage and, in turn, improve business performance (cf. the introductory section).

It is well documented that differentiation is an important characteristic of a strong brand (Lynch and de Chernatony, 2004). In a CEM setting differentiation has also been highlighted as important. For example, Palmer (2008) talks about how the development has gone from differentiating on "tangible features", followed by "service benefits" and later on "relationships" and now on "experimental values". Palmer (2008) argues that "...experience may be a differentiator in markets where relationships have ceased to be a point of competitive differential advantage".

The link from differentiation via market performance to financial results is evident. The model also shows a direct link between differentiation and financial results. The argument is that innovation differentiation includes, among other things, product development, new production methods and new processes, which in itself can provide financial advantages. 


\section{Methodology}

\section{Measures development}

The conceptual model's 10 variables are viewed as latent variables, which are measured by 26 measurement variables or items (measured by survey questions). The seven dimensions of CEM have been deduced from literature studies and as a result of confirmative and explorative factor analysis. The model structure is hereby supported by data which in turn makes good sense to the model (face validity).

The survey questions which have been used to measure the seven CEM dimensions are partly inspired by Colin Shaw's work with customer experience (Shaw, 2004, 2007; Shaw and Ivens, 2005), partly based on practical work with measuring CEM, and partly developed specifically for this study.

Measurements of differentiation, market performance and financial performance have been done by using established scales from academic literature. The survey questions for measuring differentiation are based on Chandler and Harris (1994) and Zhou et al. (2009). As mentioned above, differentiation includes innovation differentiation (e.g., investments in new capabilities that give advantage compared to competitors, and meets the customer's needs in new ways) and market differentiation (e.g., unique products and services, and nobody can easily copy the company). The survey questions for measuring market performance and financial performance are based on Desphandé et al. (1993), Homburg and Pflesser (2000), Moorman and Rust (1999), and Zhou et al. (2009). Market performance is measured by customer perceived product and service quality, customer satisfaction, customer loyalty, attracting new customers and company image, and financial performance is measured by market share, turnover, gross operating profit, productivity and return on invested capital.

All questions are generic which means they are formulated in such a flexible manner that they can be used across companies and industries. Hereby the estimation results can be compared across companies and industries which give the opportunity to use the results in benchmarking studies. This is an obvious advantage for this model and the attached measurement system.

The developed questionnaire consists of 35 questions regarding CEM and 18 questions regarding differentiation and the two business performance variables.

The respondent answers all questions on a 7-point scale. Questions regarding CEM and differentiation are formulated as statements about the respondent's company where the respondent is asked about agreement from 'strongly disagree' to 'strongly agree'. Questions regarding performance are to be answered on a scale from 'much worse' to 'much better' compared to competitors.

\section{Data collection}

In 2010 we conducted an online survey across several industry and service sectors in Denmark to capture a broad variety of market settings. Our unit of analysis is the company, and the data contains 484 useable interviews with managers of companies in Denmark. Most 
of the managers held top management positions such as marketing manager/director (responsible for marketing and sales activities within the company) or member of the Executive. The respondents evaluated the ability of CEM in their company as well as their company's differentiation in the market and business performance.

\section{A structural equation modeling approach}

The conceptual model in Figure 1 is operationalized as a structural equation model which links each latent variable with the corresponding measurement variables (the measurement model), and links the latent variables through causal relationships (the structural model) symbolized by the arrows in the Figure 1 .

The structural equation model was estimated and tested by using partial least squares (PLS) due to this method's advantages: PLS is distribution-free, it is robust (against skew distributions for measurement variables and multicollinearity) (Cassell et al., 1999; Chin, 1998; Fornell and Bookstein, 1982; Hulland, 1999; Tenenhaus et al., 2005). Furthermore, PLS is a powerful method for predictive applications, as PLS aims at explaining variances (Fornell and Cha, 1994).

We followed the recommended two-stage analytical procedure for the PLS approach to structural equation modeling (Fornell and Larcker, 1981; Hair et al., 2012; Hulland, 1999): First, the measurement model was evaluated, then the structural model was evaluated, including estimation and testing of the model. In both stages the software SmartPLS (Ringle et al., 2005) was used.

\section{Results}

\section{Measurement model evaluation}

Initially, several analyses were carried out to assess the measurement variables (items) and the latent variables in the model. The original $35 \mathrm{CEM}$ items (survey questions) were for the model estimation reduced to 23 items based on the analyses of reliability and validity. It was also during this phase as mentioned above explorative and confirmative factor analysis were carried out that supported the model structure.

We examined the reliability and validity of the scales. First, item reliability is established if the factor loading of an item is 0.7 or more (Carmines and Zeller, 1979; Hulland, 1999). We found from the SmartPLS output, that the lowest loading was 0.72, indicating that item reliability of the scale measures was acceptable. Second, composite reliability (internal consistency) was assessed using the composite reliability coefficient recommended by PLS researchers, and acceptable level are said to be 0.7 or higher (Baumgartner and Homburg, 1996; Chin, 1998; Fornell and Larcker, 1981; Hulland, 1999). We found that all composite reliability coefficients were greater than 0.82 and exceeds the recommended threshold. In addition, we also used the average variance extracted (AVE), which should be greater than 0.5 (Chin, 1998; Fornell and Cha, 1994; Fornell and Larcker, 1981). The AVE for all latent variables exceed clearly this condition, since the lowest reported AVE value was 0.55 , demonstrating composite reliability for all latent variables also in this way. Third, 
discriminant validity is present if the square root of AVE of a latent variable is larger than its correlations with the other latent variables (Chin, 1998; Fornell and Larcker, 1981; Hulland, 1999). This criterion is meet for all latent variables, which indicates that the latent variables in the model are distinct. Thus, with acceptable reliability and validity assessments our measures were considered to be appropriate for subsequent estimation and test of the causal model.

\section{Structural model evaluation}

The results of the PLS estimation of the model are shown in Figure 2. The estimates of the impacts (path coefficients) between the latent variables in the model are shown by the arrows in Figure 2, and ability and performance indexes of the latent variables are shown inside the variables in the figure. All estimated impacts are positive, as expected. The estimated indexes for each variable - from 0 (poor) to 100 (excellent) - indicate the average level among the participating companies in the study. The impact scores are effects of a one point increase in a variables' index on the subsequent variable.

To test the significance of the path coefficients the bootstrap resampling procedure is applied, and all relationships in the model are statistically significant at the $5 \%$ level $(\mathrm{p}<0.05)$ and six of the 10 relationships are also significant at the $1 \%$ level $(\mathrm{p}<0.01)$.

By estimating the model an explanatory power of $\mathrm{R}^{2}=0.58$ for financial performance is achieved, i.e. $58 \%$ of the variation in financial performance is explained by the model. For market performance and differentiation the explanatory power is respectively 0.47 and 0.38 . These $\mathrm{R}^{2}$ values indicate good overall model fit.

In conclusion, the quality of the model is good with substantial explanatory power. Thus, there is great certainty and precision in the results and conclusions to be drawn from the study.

\section{Discussion}

\section{Clear evidence of the relationship between CEM and financial performance}

The model estimation results show that there is a strong relationship between CEM and financial performance as illustrated in Figure 2. All CEM dimensions have a positive influence on differentiation, which in turn has a positive and significant influence on both market performance and financial performance. And as expected, market performance influence financial performance.

Based on the estimated impacts, it is possible to calculate the impact of different improvements in CEM. For example, a simultaneously improvement in all CEM dimensions of $10 \%$ gives a $9 \%$ increase in differentiation and a $5 \%$ increase in financial performance. 
Figure 2. The estimated CEM model

\section{Customer Experience Management}

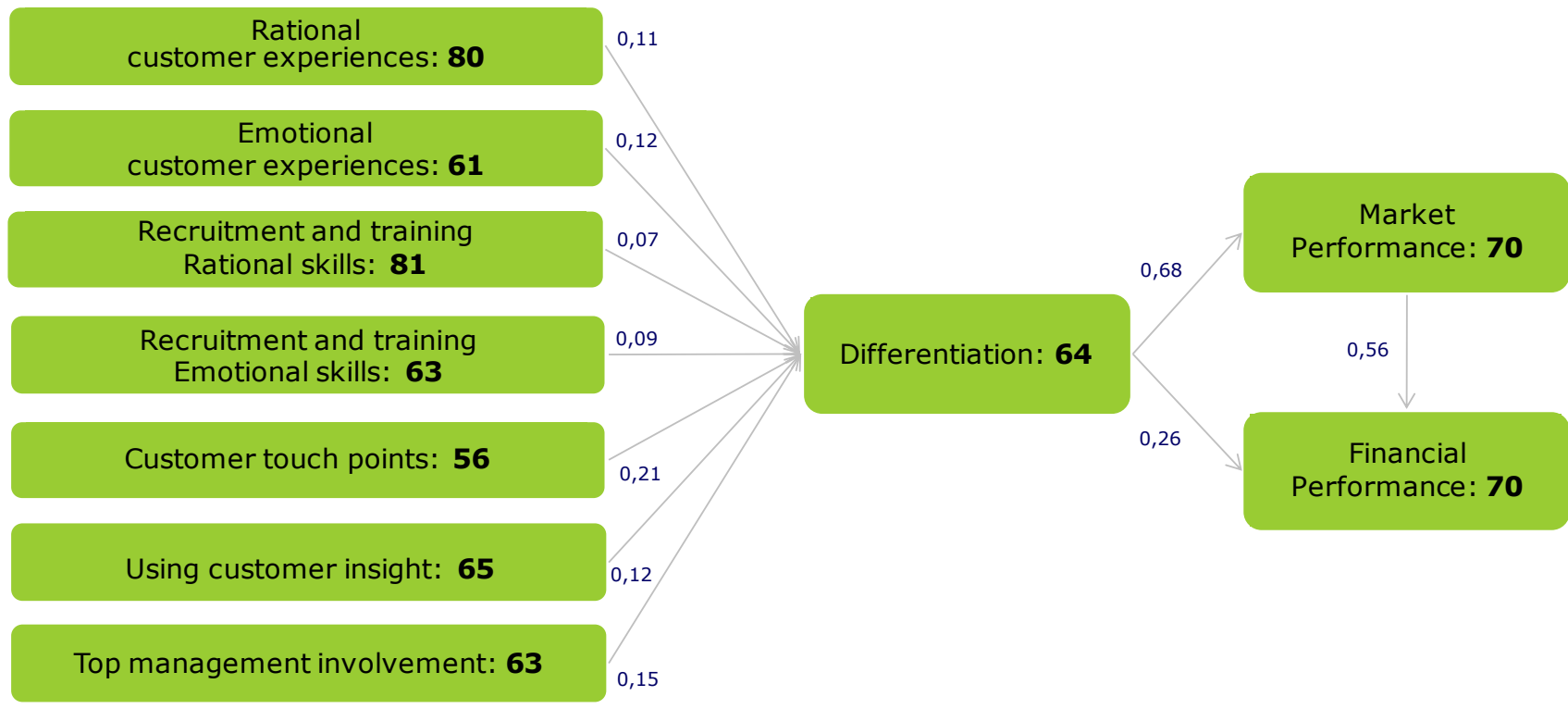

\section{Differences between the CEM dimensions}

Huge differences exist between the seven indexes for the ability of the CEM dimensions. The highest ability index is 80 for rational customer experiences which include rational aspects of customer experience objectives, customer focus in the organization, measuring customer experiences, customer driven innovation and branding, i.e. delivering a customer experience true to the brand promise. In general, the analyzed companies are good at these rational components of product and service experiences. However, when it comes to the emotional components an index of only 61 is achieved. Thus, companies find that they are not as good at creating emotional customer experiences as creating rational customer experiences.

The same pattern is seen for employee recruitment and training where companies focus on rational competencies and skills (index 81) whereas the emotional aspects certainly are less in focus (index 63).

The lowest ability index is 56 , which is obtained for customer touch points, i.e. specifying all touch points between the customer and the company and having a formalized description of the desired rational as well as the emotional customer experience at these touch points. The companies find their capability on this dimension poorest compared to the other six dimensions.

Figure 2 shows the estimated impacts of each of the CEM dimensions in creating differentiation and subsequently financial results. The most important dimension is customer touch points which relatively accounts for $24 \%$ of the total impact of CEM, and top management involvement accounts for $17 \%$ of the total impact. These two dimensions are able to account for $41 \%$ of the companies' ability to create differentiation. Customer focus is 
essential for both these most important dimensions by implementing customer focus in all customer touch points and ensuring customer focus at top management level.

CEM ability indexes and impacts can be combined in a scatter plot as the one shown in Figure 3. This figure shows that the most important dimension, customer touch points, has the lowest index score. Companies should concentrate their efforts here to improve customer experiences and financial performance.

It is also noticeable that the rational dimensions score high - the companies do well here while the emotional dimensions score low. Today companies are relatively good at planning a rational customer experience. However, customers' emotional experiences need to be strengthened and there is room for improvement if companies want to build better total customer experiences.

\section{High versus low performing companies}

It is possible to split the managers' responses into two groups: (1) managers who evaluate, that their company has good financial results compared to their competitors, and (2) managers who evaluate, that their company has bad financial results. A comparison of the $20 \%$ best financial performing companies (top 20\%) with the $20 \%$ worst financial performing companies (bottom 20\%) reveals significant differences in their CEM ability.

Figure 4 shows the manager's answers to two selected questions regarding the two most vital CEM dimensions. It is evident that the differences between high performers and low performers are significant.

Regarding customer touch points we find the greatest differences between high performing companies (top 20\%) and low performing companies (bottom 20\%). The companies which have defined and described the touch points from the customers' point of view are also the companies which perform best financially. However, one thing is to describe each touch point both rationally and emotionally, another is to measure it and set objectives for what the customer should experience. This study distinguishes between the objectives for the rational and the emotional elements of the customer experience. Again the study shows that there is a significant difference between high performers and low performers when it comes to setting objectives for the rational elements of the customer experience. Interestingly, this difference is not seen when the question revolves around setting objectives for the emotional elements of the customer experience. This is possibly a result of the fact that many Danish companies have not finished the implementation of CEM and thereby the measurement of the emotional elements. Today, focus is obviously on more rational elements, however, there is an obvious potential in working more purposeful with the emotional experiences which will be discussed in the following section. 
Figure 3. Impact versus ability of CEM dimensions in driving financial performance

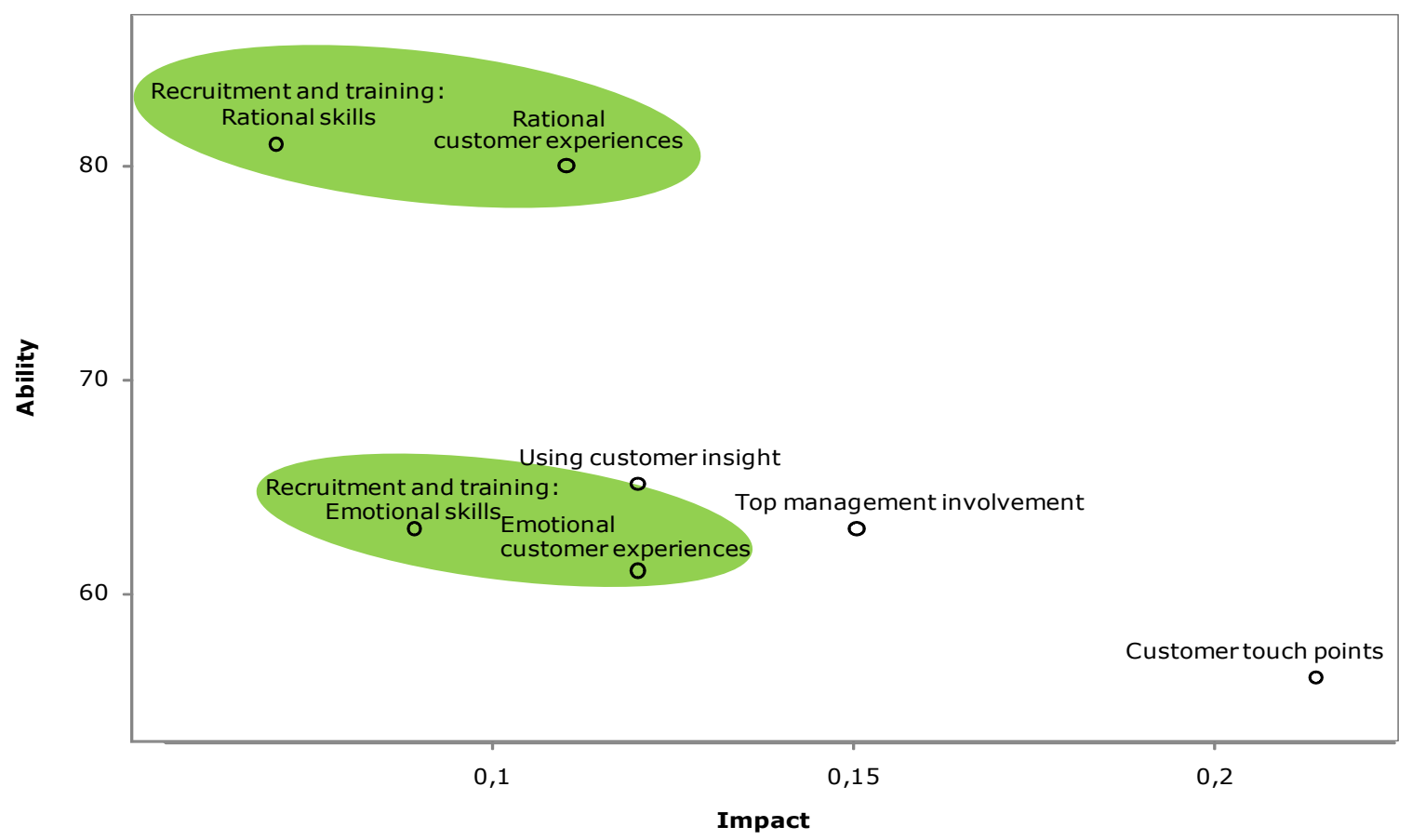

Figure 4. High performers' and low performers' response to selected survey questions
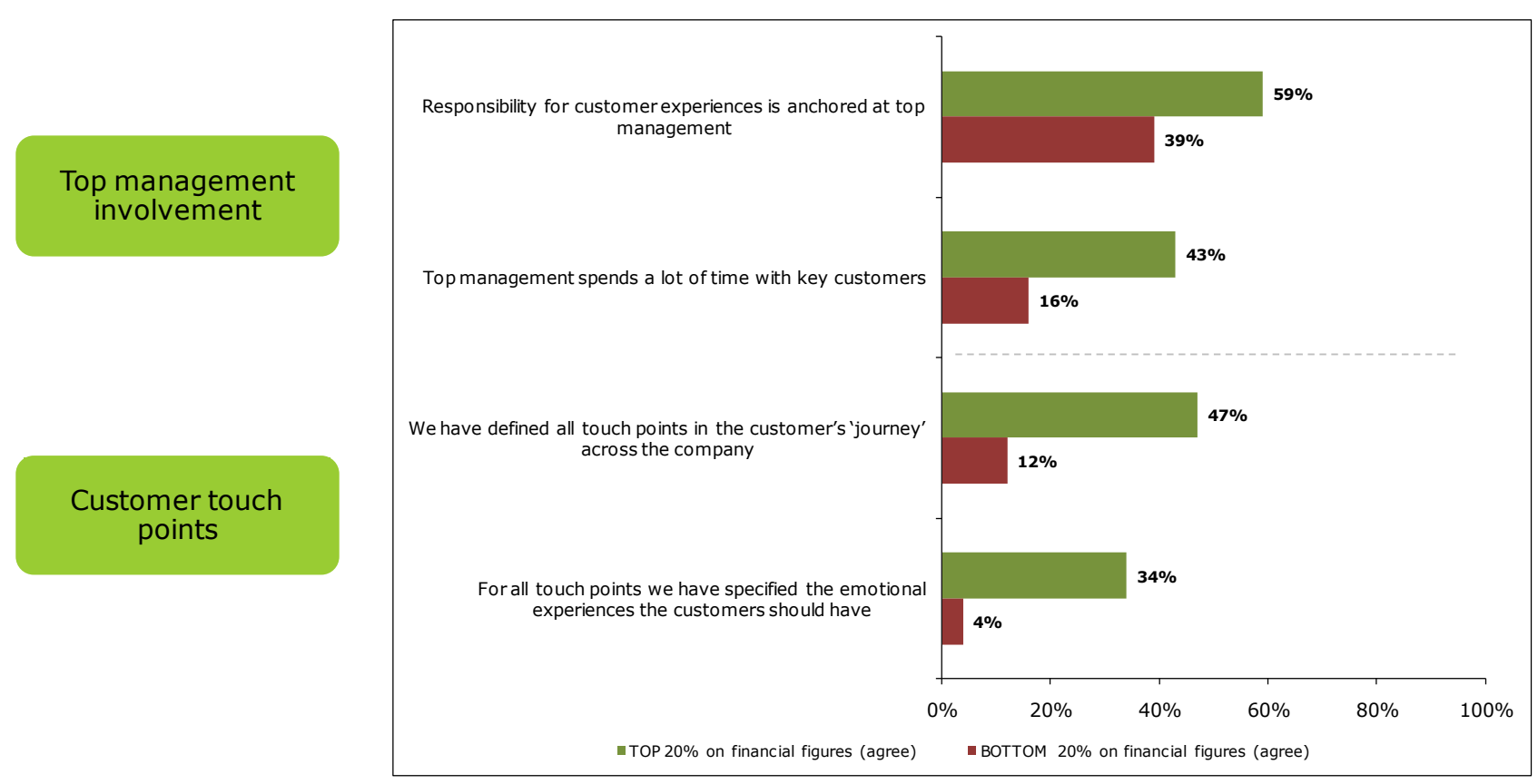
This study shows that Danish companies focus mostly on the rational customer experiences and employee skills. However, the emotional components have approximately the same impact on financial performance indicating that emotional components in customer experiences and employee skills need to be strengthened.

Since companies today are relatively good at planning the rational components of touch points and experiences there is a need to focus on the emotional components of customers' touch points and experiences. One could rhetorically say that when the greatest part of a consumer decision is taken emotionally why not improve the emotional components?

This study explores whether emotional and rational elements are included in the companies' work with CEM. In all CEM area there are significant differences between the ability to build on rational and emotional aspects in the CEM (Figure 5).

This study confirms that companies with good abilities of working with both emotional and rational aspects of CEM are the ones that achieve the best financial results.

This becomes even more evident when looking at the top $20 \%$ financial performing companies' answers to the same questions divided into rational as well as emotional aspects (Figure 6). Two points of views can be emphasized: (1) High performing companies demonstrate the best abilities of working with both the emotional and the rational aspects of CEM. (2) High performing companies have a more balanced focus on the emotional and the rational aspects of CEM.

\section{Managerial implications}

This study has practical implications for creating and delivering customer experiences. CEM allows companies to develop a customer-oriented strategy by understanding key dimensions of CEM and their role as drivers of business performance. In this section implications regarding customer touch points and customer insight will be highlighted.

The most important CEM dimension is customer touch points. To ensure that the customer receives the planned experience it is crucial to know all of the customer's touch points with the company. When these have been mapped out, key touch points must be identified and crucial synergies across touch points have to be defined. This gives the foundation for the next step and specifies how the customer should experience the company at each touch point. Some companies are working with tools such as customer journey map and blueprint for key touch points where the desired customer experiences are specified. This can be organized according to which element has to deliver the desired experience and the elements which absolutely must not occur. Crucial for the effect of the described touch points is that both emotional and rational components of the customer's experience are specified for each touch point. Drawing upon research and case studies Frow and Payne (2007, p. 98-99) suggest that companies seeking to deliver an outstanding or perfect customer experience should especially focus on 11 issues. Two of these are "carefully managing customer touch points" and "ensure a consistent customer experience within and across multiple channels" and touch points. 


\section{Figure 5. Response to selected survey questions regarding rational and emotional aspects}

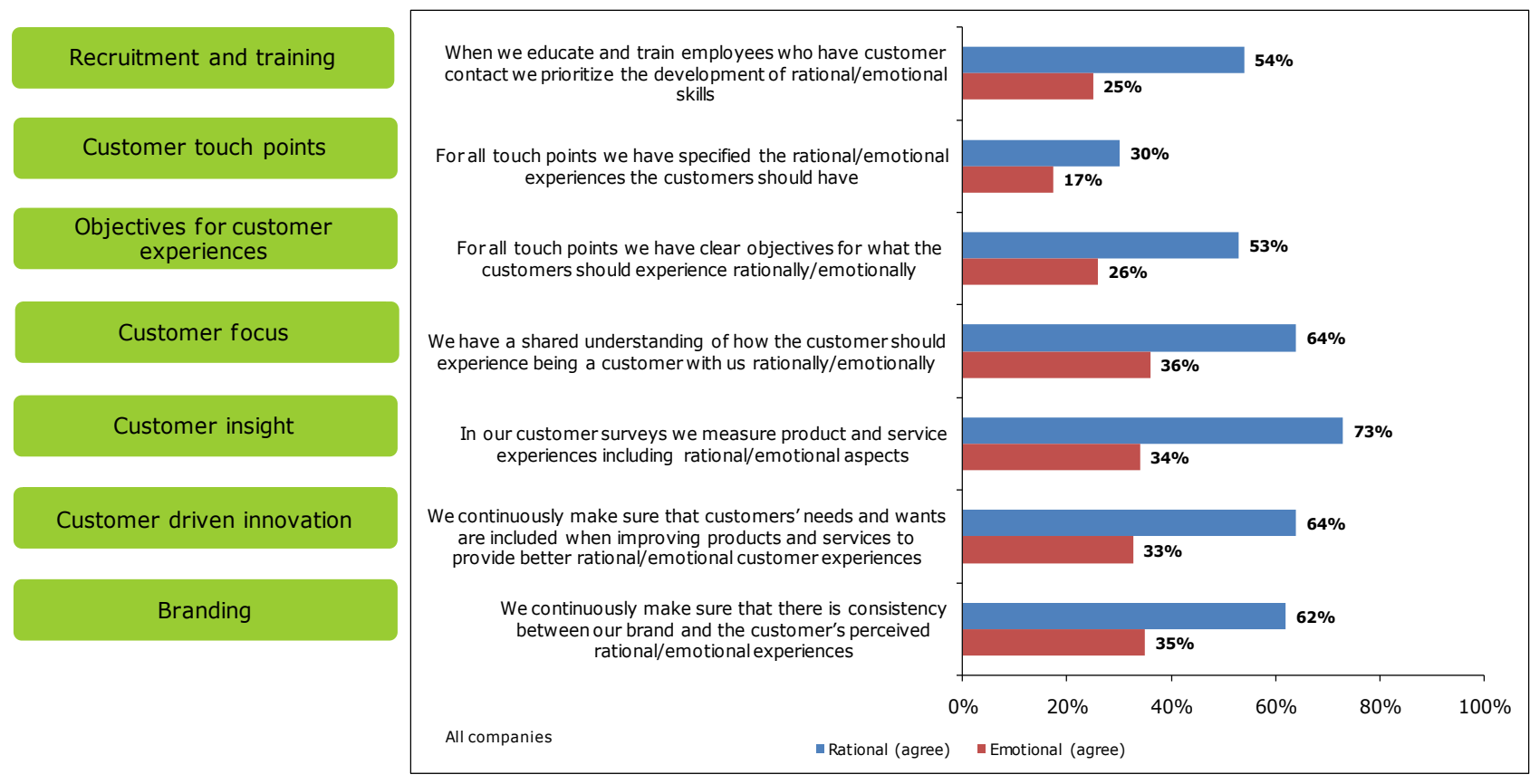

Figure 6. High performers' response to selected survey questions regarding rational and emotional aspects

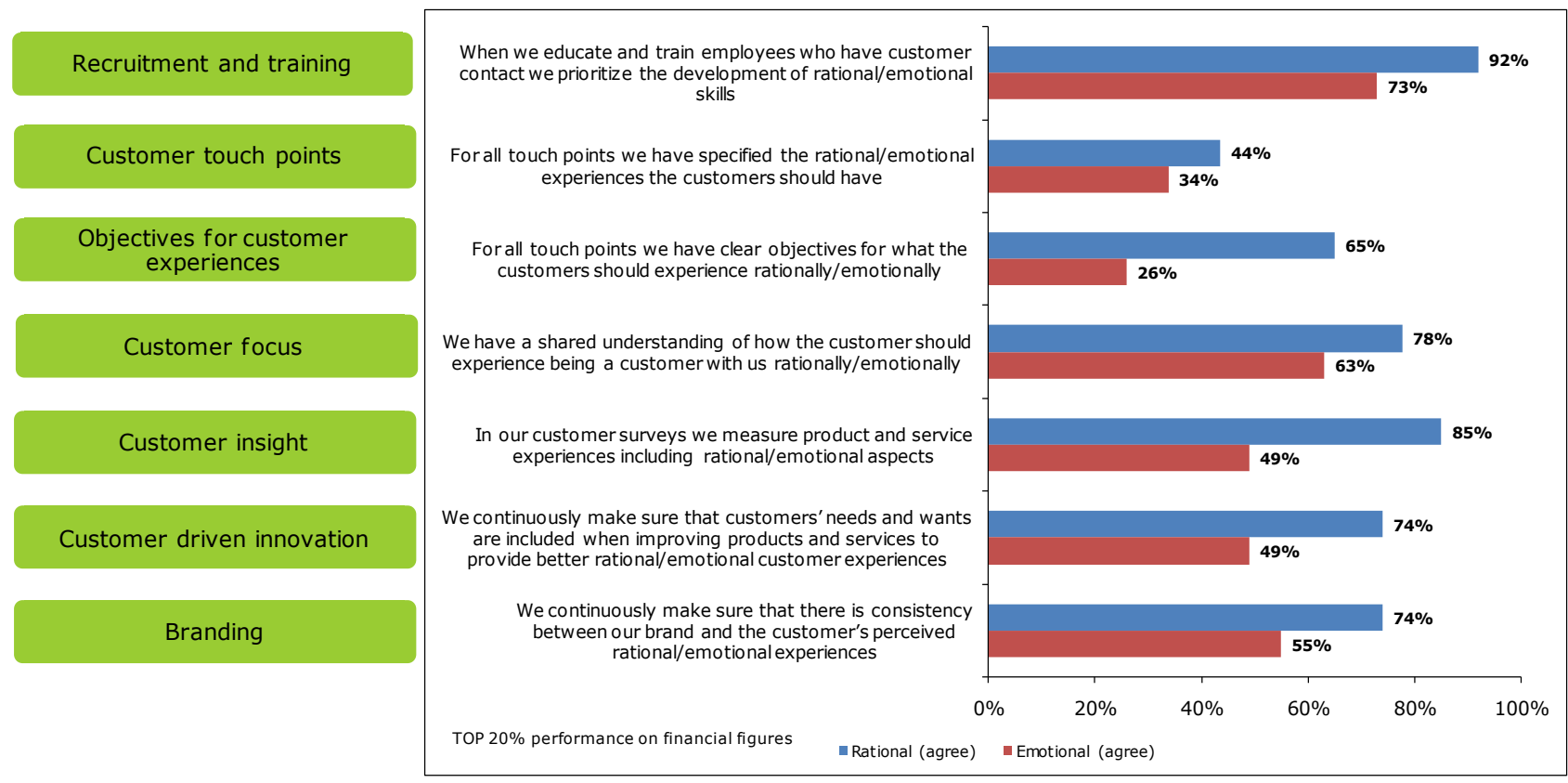


CEM is crucial as it ensures successful ongoing customer relationships by taking a broader view on all touch points and interdependencies.

Hogan et al. (2005, p. 11) highlight the prioritizing of CEM improvements in touch points: "It's critical to analyze which touch points will have the greatest impact, both positive and negative, on customer behavior and loyalty and then reallocate investments to those few key touch points".

Research indicates that it is important for customers to become co-creators of their experiences (Gentile et al., 2007). Customers should be included in concretizing all touch points and visualizing the kind of experience they want to have. This relates both to the direct and indirect touch points such as word of mouth, advertising, and other communications. The customer's total experience of the company and its products is a synthesis of all direct and indirect touch points.

To concretize and develop the right touch points important to the customer requires a dialogue with the customer. Today, most customers know exactly what they do not want, but they may be slightly more uncertain of - or find it hard to express clearly - what they actually do want. That is why dialogue between the customer and the company/employee is important. The study indicates that there is much to gain by having an inspiring and constructive dialogue with the customers. The CEM dimension using customer insight includes the use of customer insight in customer dialogue and has an index score of 65 indicating good potential for improvement across the analyzed companies.

In the second section, customer insight is mentioned as a characteristic of CEM, and the use of customer insight is a CEM dimension in the developed model (Figure 1 and 2). An essential prerequisite for the great experience is that it is founded in the customers' real needs and hence will contribute to the positive differentiation of the company. To ensure the best fit between customer needs and how the company actually delivers the great customer experience, a systematic approach for collecting customer insight has to be implemented. It could be surveys, targeted studies, observational studies, and "voice of customer" research (Meyer and Schwager, 2007, p. 120). The customer insight should be collected at all key touch points, and the information should be used of "business or functional leaders, in order to create fulfillable expectations and better experiences with product and services" (Meyer and Schwager, 2007, p. 120).

\section{Conclusion}

This paper has investigated CEM and its influence on business performance. The developed CEM model provides a comprehensive means of covering important dimensions of CEM as well as a better understanding of these dimensions' link to business performance. The seven CEM dimensions make good sense to Danish managers. The model has been empirically validated, and all relationships in the model are statistically significant indicating a solid model. The quality of the model is good with substantial explanatory power, and the conclusions drawn from this study reflects high confidence and precision. 
The data presented in the paper provide evidence that all the seven CEM dimensions influence financial performance. The findings reveal that high performing companies master better the CEM compared to low performing companies.

The presented model is limited to seven identified CEM dimensions. It is possible that an alternative structure of the dimensions or new dimensions - cf. the introductory remarks on the growing literature and debate on CEM - may provide even more powerful conclusions.

This study was the start of a yearly CEMindex that measures CEM, based on the same survey set-up and modeling approach as presented in this paper. Some survey questions are added during the years to reveal actual CEM themes and trends. The CEMindex is conducted by Rambøll Management Consulting in collaboration with Copenhagen Business School. The first CEMindex report was published in 2011, and the latest version of a report with 2014 findings was released in the spring of 2014. A practitioner report on CEMindex 2014 can be ordered on the website www.sjp.dk/en.

\section{References}

Balakrishnan, M.S. (2011), "Gain the most from your marketing spend on loyalty", Business Strategy Series, Vol. 12, No. 5, pp. 219-225.

Baumgartner, H., and Homburg, C. (1996), "Applications of structural equation modeling in marketing and consumer research: A review", International Journal of Research in Marketing, Vol. 13, pp. 139-161.

Brakus, J. J., Schmitt, B.H., and Zarantonello, L. (2009), "Brand experience: What is it? How is it measured? Does it affect loyalty?", Journal of Marketing, Vol. 73, May, pp. 52-68.

Carmines, E.G., and Zeller, R.A. (1979), Reliability and Validity Assessment, Sage University Paper Series on Quantitative Applications in the Social Sciences, No. 07-017. Sage, Beverly Hills, California.

Chandler, G., and Hanks, S.H. (1994), "Market attractiveness, resource-based capabilities, venture strategies, and venture performance", Journal of Business Venturing, Vol. 9, July, pp. 331-349.

Chin, W.W. (1998), "The partial least squares approach to structural equation modeling", in: Marcoulides, G.A. (Ed.), Modern Methods for Business Research (pp. 295-336). Lawrence Erlbaum Associates, Mahwah, New Jersey.

Deshpandé, R., Farley, J.U., \& Webster Jr., F. (1993), "Corporate culture, customer orientation, and innovativeness in Japanese firms: A Quadrad analysis", Journal of Marketing, Vol. 57, No. 1, pp. 23-37.

Fornell, C. and Bookstein, F.L (1982), "Two structural equation models: LISREL and PLS applied to consumer exit-voice theory", Journal of Marketing Research, Vol. 19, No. 4, pp. 440-452.

Fornell, C. and Cha, J. (1994), "Partial least squares", in: R.P. Bagozzi (Ed.), Advanced Methods of Marketing Research (pp. 52-78). Blackwell, Cambridge, Massachusetts.

Fornell, C. and Larcker, D.F. (1981), "Evaluating structural equation models with unobservable variables and measurement error", Journal of Marketing Research, Vol. 18, No. 1, pp. 39-50. 
Frow, P. and Payne, A. (2007), "Towards the 'perfect' customer experience", Journal of Brand Management, Vol. 15, No. 2, pp. 89-101.

Gentile, C., Spiller, N., and Noci, G. (2007), "How to sustain the customer experience: An overview of experience components that co-create value with the customer", European Management Journal, Vol. 25, No. 5, pp. 395-410.

Hair, J.F., Sarstedt, M., Pieper, T.M., and Ringle, C.M. (2012), "The use of partial least squares structural equation modeling in strategic management research: A review of past practices and recommendations for future applications", Long Range Planning, Vol. 45, No. 5/6, pp. 320-340.

Hogan, C., Almquist, E., and Glynn, S.E. (2005), "Brand building: Finding the touchpoints that count", Journal of Business Strategy, Vol. 21, No. 2, pp. 11-18.

Homburg, C. and Pflesser, C. (2000), "A multiple-layer model of market-oriented organizational culture: Measurement issues and performance outcomes", Journal of Marketing, Vol. 37, No. 4, pp. 449-462.

Hulland, J. (1999), "Use of partial least squares (PLS) in strategic management research: A review of four recent studies", Strategic Management Journal, Vol. 20, No. 2, pp. 195204.

Kershaw, S. (2011), "It's time B2B got emotional”, Marketing, 11 May, pp. 33-34.

Kotler, P. and Pfoertsch, W. (2006). B2B Brand Management, Springer, Heidelberg/New York.

Lynch, J. and de Chernatony, L. (2004), "The power of emotion: Brand communication in business-to-business markets", Brand Management, Vol. 11, No. 5, pp. 403-419.

Lywood, J., Stone, M., and Ekinci, Y. (2009), "Customer experience and profitability: An application of the empathy rating index (ERIC) in UK call centres", Journal of Database Marketing and Customer Strategy Management, Vol. 16, No. 3, pp. 207-214.

Meyer, C. and Schwager, A. (2007). "Understanding customer experience", Harvard Business Review, Vol. 85, No. 2, pp. 117-126.

Mascarenhas, O.A., Kesavan, R., and Bernacchi, M. (2006), "Lasting customer loyalty: A total customer experience approach", Journal of Consumer Marketing, Vol. 23, No 7, pp. 397-405.

Moorman, C. and Rust, R.T. (1999). "The role of marketing", Journal of Marketing, Vol. 63, No. 4, pp. $180-197$.

Palmer, A. (2008), "The role of the 'customer experience manager' - Hope or hype?", Proceedings of the 10th International Research Seminar in Services Management, La Londe, France, 27-30 May 2008.

Palmer, A. (2010), "Customer experience management: a critical review of an emerging idea", Journal of Services Marketing, Vol. 24, No. 3, pp. 196-208.

Pine, B.J. and Gilmore, J.H. (1998), The Experience Economy, Harvard Business School Press, Boston, Massachusetts.

Pullman, C. and Gross, M.A. (1999). "Ability of experience design elements to elicit emotions and loyalty behaviors", Decision Sciences, Vol. 5, No 3, pp. 551-578.

Schmitt, B. (1999). Experimental Marketing: How to Get Customers to Sense, Feel, Think, Act and Relate to Your Company and Brands, The Free Press, New York, NY.

Sharma, M. and Chaubey, D.S. (2014). "An empirical study of customer experience and its relationship with customer satisfaction towards the services of banking sector", Journal of Marketing \& Communication, Vol. 9, No 3, pp. 18-27.

Shaw, C. (2004), Revolutionize Your Customer Experience, Palgrave Macmillan, New York.

Shaw, C. and Ivens, J. (2005), Building Great Customer Experiences, Prentice-Hall, London. 
Shaw, C. (2007), The DNA of Customer Experience: How Emotions Drive Value, Palgrave Macmillan, New York.

Tumbat, G. (2011), "Co-constructing the service experience: exploring the role of customer emotion management", Marketing Theory, Vol. 11, No. 2, pp. 187-206.

Verhoef, P.C., Lemon, K.N., Parasuraman, A., Roggeveen, A., Tsiros, M., and Schlesinger, L.A. (2009), "Customer experience creation: Determinants, dynamics and management strategies", Journal of Retailing, Vol. 85, No 1, pp. 31-41.

Zhou, K.Z., Brown, J.R., and Dev, C.S. (2009), "Market orientation, competitive advantage, and performance: A demand-based perspective", Journal of Business Research, Vol. 62, No. 11, pp. 1063-1070. 